\title{
Language, gender and sexuality in South Africa
}

\author{
Tommaso M. Milani \\ Linguistics, University of the Witwatersrand, Johannesburg, South Africa \\ E-mail: Tommaso.Milani@,wits.ac.za
}

This special issue on the theme of language, gender and sexuality in South Africa does not emerge in an academic vacuum. It is the continuation of a long-standing academic dialogue which has played out, inter alia, in two issues of the journal Southern African Linguistics and Applied Language Studies dedicated to "gender and language" (de Kadt 2002), and "language and gender" (Reddy and de Kadt 2006), respectively ${ }^{1}$, as well as in a recent edited collection entitled Gender and Language in Sub-Saharan Africa: Tradition, Struggle and Change (Atanga, Ellece, Litosseliti and Sunderland 2013). In contrast, this special issue seeks explicitly to foreground sexuality as a category of investigation in its own right alongside gender. Of course, this is not to say that previous scholarship has ignored sexuality - quite the contrary (see e.g. Reddy (2002) on homophobia in Southern Africa, and Reddy and Potgieter (2006) on the Zuma rape trial). Yet it is striking how analyses of language and sexuality have generally been framed under the umbrella titles of "language and gender"/"gender and language".

Critical discourse analyst Teun van Dijk (1998, cited in Wodak 2000: 196) reminds us that titles are ideological tools; they constitute "macro-propositions" that frame, summarise, and foreground what will be said later. His observations target print journalism, but they could be applied to any process of entextualisation (Silverstein and Urban 1996), including academic writing. To this it could be added that any choice of label is inherently political. As linguistic anthropologist Susan Gal notes,

the selection of a term that picks out a referent involves a delicate (and not always conscious or aware) negotiation of social relationships, assumptions about participants' levels and types of knowledge, hence their identities and social location. In turn, the use of one rather than another referring expression is creative/performative. [...] Each claims a speaker identity, positions speakers with respect to each other, with respect to the event, the referent, and to the cultural discourses indexed by the labels selected.

(Gal 2006: 177)

Like van Dijk, Gal is not writing about academic discourse, but her considerations on the politics of naming are inescapably germane for any reflection on labelling practices, including

\footnotetext{
${ }^{1}$ The different order "language and gender"/"gender and language" is not random, but is symptomatic of different foci that highlight one element of the pair vis-à-vis the other.
} 
academic ones. So to foreground sexuality alongside gender in this special issue is not a terminological triviality, but is a linguistic choice with a political aim.

I want to state upfront that advocating a bifocal lens on gender and sexuality is not equivalent to ignoring how deeply interrelated they are, nor is it a derailing strategy aiming to deemphasise feminist concerns about gender inequality and oppression. Rather, the point is that acknowledging that "[s]exuality and gender may be interdependent" does not entail that they are "reducible to one another" (Cameron and Kulick 2003: 53). In saying so, I want to recast Gayle Rubin's (1984: 170) suggestion that “feminism's critique of gender hierarchy must be incorporated into a radical theory of sex, and the critique of sexual oppression should enrich feminism". An explicit focus on sexuality also forces us to explore how the domain of desire and the erotic manifest themselves semiotically, and are imbricated in the production of particular power relations with specific socio-historical situatedness (Cameron and Kulick 2003). To quote Rubin (1984: 149) once again, “[a] radical theory of sex must identify, describe, explain, and denounce erotic injustice and sexual oppression”.

It is precisely issues of erotic injustice and sexual oppression that are addressed by the two articles that open this special issue, which look at media representations of rape and sex workers, respectively. Jana Krige and Marcelyn Oostendorp's diachronic investigation of the advice column Dear Dolly in the well-known Drum Magazine shows how representations of victims and perpetrators have undergone an interesting, albeit problematic and sexist, change after South Africa's transition to democracy. Whereas overt "blame-the-victim" strategies were most common in apartheid times, more covert tactics of victim-blaming seem to have become common after 1994. As the authors point out, post-apartheid women might be constructed as empowered "to decide who they can have sex with [and] to decide to lay charges without sanction and fear. However, the conditions which very often force women not to report rape are not scrutinised, and are in fact reinforced by rape myths such as 'If it was rape she would have reported it immediately after it happened"' (Krige and Oostendorp, this issue).

An ambivalent and problematic pattern of representation also emerges from Sally Hunt and Beatrice Hubbard's corpus-assisted critical discourse analysis of sex work(ers) in the newspapers The Sowetan and the Mail \& Guardian within the context of debates about the decriminalisation of sex work in conjunction with the 2010 FIFA World Cup. Both publications implement a gendering process that portrays sex work as a dangerous occupation conducted by heterosexual women. Police harassment is singled out as one of the main themes in both corpora. Interestingly, The Sowetan reports on the targeting of black sex workers by police, and thus foregrounds a racial element in police abuse. The Mail \& Guardian instead erases any reference to race by representing "all sex workers as human beings who are victims of unacceptable abuses of power" (Hunt and Hubbard, this issue). Moreover, a comparison of the two corpora shows that the Mail \& Guardian invokes human-rights discourses through which it strongly argues for a decriminalisation of sex work. In contrast, The Sowetan reproduces a view of sex work as immoral or as a disease. This finding leads the authors to conclude that "the coverage in The Sowetan [...] reveals that South African society [...] still clings with steadfast tenacity to views of women in general, and sex workers in particular, which are firmly rooted in patriarchy. Ultimately, this reproduces assumptions and subject positions which further marginalise and disempower those whose access to agency is already precarious and circumscribed" (Hunt and Hubbard, this issue). 
While the first two contributions to this special issue focus on the intersections of gender and heterosexuality, the following articles zoom in on homosexuality with the help of a variety of "queer" linguistic approaches to textual analysis. All the authors here, however, do not unanimously agree on the applicability of "queer" to South African conditions (see also McEwen and Milani (2014) for a discussion).

Thabo Msibi and Stephanie Rudwick study men who have sex with other men and identify as skesana ${ }^{2}$ in KwaZulu-Natal. With the help of an ethnographic methodology, the authors reveal how these men's linguistic practices simultaneously speak back to homophobia and reproduce a heteronormative gender order. According to the authors, this not only serves as a testimony to "the dominance of patriarchy in a transformed, 'equal' post-apartheid South Africa, but also highlights the extent to which fixed binary systems inform gender practices" (Msibi and Rudwick, this issue).

Using a different methodological technique, Lauren Mongie's article offers quantitative evidence of the discursive means employed by the newspapers City Press and the Mail \& Guardian in framing South Africa's "gay liberation movement" over a period of 25 years (1982-2006). Drawing upon van Dijk's (1993) approach to critical discourse analysis, Mongie demonstrates how liberation, rights, victimisation, religion, morality and nature occurred over and over again in the newspaper corpora as the main frames employed by both publications. The difference, however, lies in the ways in which City Press used these frames to express anti-gay sentiments, while the Mail \& Guardian primarily deployed the same frames to express pro-gay sentiments.

Of course, the very choice of "gay" as a hypernym of sexual liberation is not innocuous, but is itself a linguistic manifestation of a masculine gendered bias that contributes to "marginalising [...] certain sub-groups within the larger group denoted by the acronym LGBT" (Motschenbacher and Stegu 2013: 524). Reasoning along similar lines, Milani and Kapa unpack the visual and linguistic strategies that foreground the intersection of certain identities, while backgrounding others, on the T-shirts used to brand Pride at the University of the Witwatersrand, Johannesburg, during the period 2011-2014. These T-shirts are textual materialisations of specific changes in the politics of visibility that aim at the empowerment of non-normative genders and sexualities on university campus. "If one were to imagine that each T-shirt is a corporeal embodiment of Wits Pride," Milani and Kapa suggest, "then this body has changed considerably in four years: from a gay man who is (supposedly) ashamed of voicing his sexual identity; into a camp though masculine figure that loudly urges to counter racial division within same-sex desire; into a more multi-faceted individual who proudly carries their gender and sexual uniqueness; and finally, into an activist who, in tension with the complex intersections that underpin discrimination, is perhaps a little reluctant to foreground gender and sexuality at all" (Milani and Kapa, this issue). Overall, the article shows how very different nexus points of gender, sexuality and race have been made visible (or not) in the pursuit of a more equal university campus.

Now that sexual rights are enshrined in the Constitution and same-sex couples have been granted the right to marry, this special issue concludes with Tracey Lee McCormick's timely critique of same-sex marriage in contemporary South African discourse. Through a close reading of To Have and to Hold (Judge, Manion and De Waal 2008), one of the key texts on the same-sex marriage

\footnotetext{
${ }^{2}$ Skesana are "men who construct themselves as feminine and who mainly play a receptive role in same-sex sexual engagements" (Msibi and Rudwick, this issue).
} 
debate, McCormick questions the prioritisation of the same-sex marriage issue in South African sexual politics, and concludes by arguing that, in "To Have and to Hold, a particular form of subjectivity is produced around the institution of marriage. On the one hand, marriage is seen as problematic but, on the other hand, the problems associated with marriage are erased in order to produce a coherent account of the power of same-sex marriage to transform all the problematic norms associated with the institution" (McCormick, this issue).

Read together, the articles in this special issue do not subscribe to a uniform theoretical and methodological paradigm. This heterogeneity is a manifestation of the different academic trajectories of individual authors. Theoretical and methodological multiplicity is also an indication of a respectful dialogue among very different research approaches. Such diversity notwithstanding, all the articles here take gender and sexuality as vantage points through which one is able to unpack what could be called the "ambivalent life of power". The articles offer multifaceted stories about how sexual politics in South Africa has been unfolding, tracing the complex and often ambiguous ways in which gender and sexuality are entangled with each other and with several other axes of social differentiation.

\section{Acknowledgments}

I would like to thank the University of the Witwatersrand for a generous "SPARC" grant that financed the conference Discourse, Gender and Sexuality: South-South Dialogues, which was held in Johannesburg on 15-16 November 2013. Most of the papers in this special issues were first presented there. I am particularly grateful to Gilles Baro for his incredible help with the conference organisation; I am also indebted to the many colleagues who reviewed the articles in this special issue.

\section{References}

Atanga, L.L., S.E. Ellece, L. Litosseliti and J. Sunderland (Eds.) 2013. Gender and language in sub-Saharan Africa: Tradition, struggle and change. Amsterdam: John Benjamins.

Cameron, D. and D. Kulick. 2003. Language and sexuality. Cambridge: Cambridge University Press.

De Kadt, E. (Ed.) 2002. Special issue of Southern African Linguistics and Applied Language Studies 20(3): iii-189.

Gal, S. 2006. Linguistic anthropology. In K. Brown (Ed.) Encyclopedia of language and linguistics. Oxford: Elsevier. pp. 171-185.

Judge, M., A. Manion and S. de Waal (Eds.) 2008. To have and to hold: The making of samesex marriage in South Africa. Auckland Park: Fanele.

McEwen, H. and T.M. Milani. 2014. Introduction. queer \& trans Art-iculations: Decolonising gender and sexualities in the global South. Agenda 28(4): 3-8. 
Motschenbacher, H. and M. Stegu. 2013. Queer linguistic approaches to discourse. Discourse \& Society 24(5): 519-535.

Reddy, V. 2002. Perverts and sodomites: Homophobia as hate speech in Africa. Southern African Linguistics and Applied Language Studies 20(3): 163-175.

Reddy, V and E. de Kadt (Eds.) 2006. Special issue of Southern African Linguistics and Applied Language Studies 24(4): 417-557.

Reddy, V. and C. Potgieter. 2006. 'Real men stand up for the truth': Discursive meanings in the Jacob Zuma rape trial. Special issue of Southern African Linguistics and Applied Language Studies 24(4): 511-521.

Rubin, G. 1984. Thinking sex: Notes for a radical theory of the politics of sexuality. In C.S. Vance (Ed.) Pleasure and danger: Exploring female sexuality. New York: Routledge \& Kegan Paul. pp. 143-178.

Silverstein, M. and G. Urban (Eds.) 1996. Natural histories of discourse. Chicago: University of Chicago Press.

Van Dijk, T.A. 1993. Principles of critical discourse analysis. Discourse and Society 4(2): 249283.

Wodak, R. 2000. Recontextualisation and the transformation of meanings: A critical discourse analysis of decision making in EU meetings about employment policies. In S. Sarangi and M. Coulthard (Eds.) Discourse and social life. London: Longman. pp. 185-206. 